\title{
WASTE MANAGEMENT OPTIONS FOR THE COMBUSTION BY-PRODUCTS IN THE CONTEXT OF THE RETARDATION OF SOIL RESOURCES' DEPLETION
}

\author{
Małgorzata Śliwka', Małgorzata Pawul', Waldemar Kępys' ${ }^{1}$, Radosław Pomykała' \\ 1 AGH University of Science and Technology, Faculty of Mining and Geoengineering, Department of \\ Environmental Engineering and Mineral Processing, Al. Mickiewicza 30, 30-059 Kraków, Poland \\ * Corresponding author's e-mail: sliwka@agh.edu.pl
}

Received: 2017.05.15

Accepted: 2017.08.01

Published: 2017.09.01

\begin{abstract}
This paper presents the results of the preliminary experiments conducted on fly ash and bottom ash samples that were collected from a fluidised-bed boiler after biomass combustion. The purpose of the research was to determine potential possibilities of the introduction of such types of waste to soil, in accordance with the ecological engineering assumptions. The following physical and chemical properties of the analysed waste were determined: particle size distribution, $\mathrm{pH}$, chemical composition, and leaching. The chemical properties of the tested power-generation waste were essentially different, depending on the time of waste sample collection from the installation, despite the fact that other identical sampling conditions were observed: the same installation, the same combustion process, and the same type of fuel. To determine the eco-toxicity of the tested waste samples, the vegetation experiments were conducted that allowed to evaluate the influence of the tested waste samples on selected test plant species. The tests concerned for example the influence of fly ash and bottom ash on such physiological processes as seed germination and plant growth (the growth of both roots and shoots). The experiments indicated certain options of the introduction of the tested waste into soil. However, due to a considerable changeability of the waste composition and structure that presented a risk of the introduction of undesired pollutants into soil, including heavy metals, such use would be possible upon previous regular evaluation of the waste's physical, chemical, and eco-toxic properties.
\end{abstract}

Keywords: combustion by-products, fly ash, bottom ash, environment, biomass, phytotests, toxicity

\section{INTRODUCTION}

Power generation effects essentially influence all the environmental components, both directly and indirectly. Besides gas emissions, a serious environmental problem is posed by solid powergeneration waste, or the combustion by-products, originating from both coal combustion and cofiring of hard coal, biomass, and alternative fuels. The combustion by-products are characterised by a considerable instability of physical and chemical properties which generally depend on the types of fuels, boilers, combustion parameters, and the method of flue gas desulphurisation [Ahmaruzzaman 2010, Grammelis et al. 2006]. The by-products of the combustion of coal, biomass, and of the co-firing of coal, biomass, and/or alternative fuels, in the form of fly ash and bottom ash, as well as flue gas desulphurisation products (being very often components of fly ash and bottom ash), cause serious environmental problems when unprocessed and stored on heaps. The waste storage locations can become the sources of pollutant migrations to the environment. From the viewpoint of the retardation of natural soil resources' depletion, it is important to recover reasonably and effectively the minerals from the waste generated by fuel combustion, in the intention to protect the earth surface, which is a non-renewable resource, and limit environmental pollution [Kostecka and Koc-Jurczyk 2010, Kostecka 2013]. The by-products of coal combustion and co-firing are used in 
building and cement industries, road construction, mining, and agriculture [Ahmaruzzaman 2010, Pomykała et al. 2015, Kępys et al. 2014, Śliwka et al. 2013, Yao et al. 2015]. The fly ash and bottom ash generated by hard coal combustion and brown coal combustion in particular, can positively influence the physical and chemical properties of soil, owing to their high content of macro- and micro-elements, in the forms that are easily accessible to plants, as well as the low content of heavy metals [Rosik-Dulewska 2015, Pomykała and Mazurkiewicz 2015].

Biomass combustion by-products are not as often recycled as the hard or brown coal combustion ones [Uliasz-Bocheńczyk et al. 2015]. That is mainly due to a different chemical and phase composition of the former [Gawlicki et al. 2014]. Since waste storage constitutes a final solution in waste management, extensive research has been conducted on the directions and possibilities of using the biomass combustion by-products [Kępys and Pomykała 2014, Stankowski et al. 2014, Ball et al. 2009, Antonkiewicz 2009, Poluszyńska 2013, James et al. 2012]. Owing to their high nutritious element content, the biomass combustion by-products can constitute a valuable source of elements that should return to the bio-geochemical circulation, e.g. in the form of additives improving soil properties. A high $\mathrm{SiO}_{2}$ content, especially in the case of bottom ash, can positively influence heavy soil structure. The combustion by-products can possibly be applied in deacidification of soil, owing to the products' strong alkaline nature, additionally limiting bioavailability of heavy metals to plants on polluted lands. Such a use of ashes, especially those originating from the biomass combustion, on the lands from which biomass was obtained, is recommended by the specialists [www.spalaniebiomasy.pl]. The results of the authors' own experimental studies, concerning the use of biomass combustion ashes in the environment, indicate a positive influence of that type of waste on soil properties (improving soil structure and ensuring deacidification properties), as well as the plant growth, owing to the their indispensable nutritious component content [Śliwka et al. 2017, Antonkiewicz 2009, Poluszyńska 2013, Czech et al. 2013, Bielińska et al. 2009, Ciećko et al. 2009].

Nevertheless, due to the physical and chemical properties and considerable instability of such properties, related to the types of fired biomass and the characteristics of the combustion process, combustion by-products can pose hazard to the environment because they can release pollutants [Lima et al. 2008, Berra et al. 2015, Cuenca et al. 2013], including heavy metals [Kopcewicz and Lewak 2007, Kabata-Pendias and Pendias 1999].

Our preliminary vegetation experiments were intended to evaluate potential options of the use of the biomass combustion by-products in the environment to improve soil properties on degraded and reclaimed lands, as well as on engineering structures.

The purpose of the study was to analyse the physical, chemical, and phytotoxic properties of waste originating from the biomass combustion, in respect of possible waste management methods intended for waste introduction to the environment, e.g. to improve soil properties, or as a source of mineral components for plants, or levelling and reclamation of degraded lands.

\section{MATERIALS AND METHODS}

The experimental material consisted in fly ash (PL) and bottom ash (PD), generated by the combustion of forest and agricultural biomass in a fluidised-bed boiler, operated in an industrial installation. In the vegetation experiments, we used three samples of fly ash (PL1, PL2, and PL3) and bottom ash (PD1, PD2, PD3) each, collected from the same installation, with observation of identical combustion conditions (it was the same type of biomass every time ), in the following months: March, May, and June of 2016.

An Analysette 22 Fritsch laser analyser was applied in particle composition analysis of the waste samples.

To establish chemical determinations, the studied samples were dissolved with $\mathrm{HNO}_{3} / \mathrm{HCl}$ (3:1), using a microwave mineraliser. The chemical analysis of ashes was carried out by the methods of inductively coupled plasma - atomic emission spectroscopy (ICP-AES) and inductively coupled plasma - mass spectrometry (ICP-MS).

The determination of the natural concentrations of radioactive elements: ${ }^{40} \mathrm{~K},{ }^{226} \mathrm{Ra}$, and ${ }^{232} \mathrm{Th}$ in ashes was carried out with the use of gammaray scintillation and semiconductor spectrometry.

The resistance of chemical impurities was tested in accordance with Polish Standard PN-EN 12457-2. Waste samples were mixed with distilled water, in the proportion of 1:10. The mixture was shaken in a plastic bottle during $24 \mathrm{hrs}$., fol- 
lowed by filtration through an $0.45 \mu \mathrm{m}$ filter. The value of $\mathrm{pH}$ and the impurity content was determined in the water extract, using the inductively coupled plasma - optical emission spectrometry (ICP-OES) and ICP-MS methods. The chloride content was determined by means of titration.

To determine the influence of the tested materials: bottom ash (PD) and fly ash (PL) on seed germination and plant growth and condition, preliminary vegetation experiments were conducted. The vegetation experiments were implemented and conducted in the Laboratory of the Department of Environmental Engineering and Mineral Raw Material Processing, Faculty of Mining and Geoengineering, AGH University of Science and Technology. The plant species applied in the pot experiments were the white mustard seed (Sinapis alba) and red fescue (Festuca rubra). The former (Sinapis alba) is recommended as a test species and applied in phytotests for the evaluation of substance toxicity against plants [Traczewska 2011, Śliwka et al. 2013, Baran et al. 2013]. The red fescue (Festuca rubra) is the species applied in biological land reclamation because the plant prefers alkaline soil [Góral 2001, Góral and Rola 2001, Dyguś et al. 2012].

The test plants were grown on universal substrate (pH 5.5-6.5), made of peat on the basis of coprolite (biohumus), produced by the Eisenia fetida, mixed with the waste being tested. The following waste and universal substrate mixes were used: $1: 9$ and $3: 7$ by volume (in three repetitions for each of the tested waste sample). 10 test seeds were planted in each pot, with the same volume and cross-section each. The seeds were selected in such a way that they had the same size and represented the same condition. To compare the influence of the tested waste on the development of the test plants, control specimens on universal substrate were prepared. All the control specimens were prepared in three repetitions. The plants were grown in laboratory conditions, with the assurance of identical parameters of growth for all the experimental specimens (access of light, temperature, and equal watering). Seed germination and plant growth observations were conducted during 7 days for the Sinapis alba and 14 days for the Festuca rubra. After 3 days of cultivation, germination was evaluated for the Sinapis alba, and the same was done for the Festuca rubra after 7 days. After 7 and 14 days, respectively, the shoots and roots of test plants were measured to determine the influence of waste on plant devel- opment. The observations of morphologic changes of the test plants were conducted in parallel.

The nonparametric Mann-Whitney U tests were applied in the statistical evaluation of the results obtained, with the use of the Statistica software.

\section{RESULTS}

Fly ash and bottom ash, generated by biomass combustion in a fluidised-bed boiler, used in our experiments, were characterised by diverse granulometric and chemical compositions that essentially influenced the test plant growth and development. Important differences in seed germination and plant growth were observed not only between the specimens grown with the addition of the different types of waste (bottom ash and fly ash), but also between the specimens grown with the addition of the same type of waste (PL or PD), collected from the same installation that differed only by the month of waste sample collection. The variation in physical and chemical properties of waste depends on the differentiation of biomass (but always the same kind of biomass was combusted).

\section{Physical and chemical properties of fly ash (PL)}

In the fly ash (PL) subjected to tests, the proportions of grain fractions were as follows (average proportions in the samples from three different sample collections): contents of sand fraction (PL1: 56.24\%; PL2: 52.37\%; PL3: 51.33\% and contents of dust fraction in samples (PL1: 43.76\%; PL2: 47.63\%; PL3: 48.77\%. The water extract reaction of all the samples being tested, from 3 sampling collections, indicated strong alkaline properties $(\mathrm{pH}>12.8)$. Depending on the sample, the water extract was classified either as hydroxy water, or sulphate-hydroxy-potassium water. The tested fly ashes contained $\mathrm{SiO}_{2}$ (ranging from 16 to $29.1 \%$, for 3 different collections: PL1: 21.7\%; PL2: 29.1\%; PL3: 16.1\%). Besides, those were characterised by high content of nutrients: Ca up to $153.3 \mathrm{~g} \cdot \mathrm{kg}^{-1}$ d.m. (PL1: 153.3 $\mathrm{g} \cdot \mathrm{kg}^{-1}$ d.m.; PL2: $135.30 \mathrm{~g} \cdot \mathrm{kg}^{-1}$ d.m.; PL3: 141.15 $\mathrm{g} \cdot \mathrm{kg}^{-1}$ d.m.), $\mathrm{K}$ up to $163.20 \mathrm{~g} \cdot \mathrm{kg}^{-1}$ d.m. (PL1: $163.20 \mathrm{~g} \cdot \mathrm{kg}^{-1}$ d.m.; PL2: $126.88 \mathrm{~g} \cdot \mathrm{kg}^{-1}$ d.m.; PL3: $138.65 \mathrm{~g} \cdot \mathrm{kg}^{-1}$ d.m.), P up to $51.21 \mathrm{~g} \cdot \mathrm{kg}^{-1}$ d.m. (PL1: $51.21 \mathrm{~g} \cdot \mathrm{kg}^{-1}$ d.m.; PL2: $36.52 \mathrm{~g} \cdot \mathrm{kg}^{-1}$ d.m.; 
PL3: $39.04 \mathrm{~g} \cdot \mathrm{kg}^{-1} \mathrm{~d} . \mathrm{m}$.), and Mg up to $45.58 \mathrm{~g} \cdot \mathrm{kg}^{-}$ ${ }^{1}$ d.m. (PL1: $45.58 \mathrm{~g} \cdot \mathrm{kg}^{-1}$ d.m.; PL2: $4,15 \mathrm{~g} \cdot \mathrm{kg}^{-1}$ d.m.; PL3: $39.04 \mathrm{~g} \cdot \mathrm{kg}^{-1} \mathrm{~d}$.m.). It was also found a very high content of sulphates $\left(\mathrm{SO}_{3}\right)$ in those fly ashes, ranging from 13.6 to $17.1 \%$ (distribution among the samples; PL1: 17.1\%; PL2: 13.6\%; PL3: $15.2 \%$ ), as well as the presence of toxic heavy metals: $\mathrm{Cd}$ up to $17.89 \mathrm{mg} \cdot \mathrm{kg}^{-1} \mathrm{~d} . \mathrm{m}$. (PL1: $17.89 \mathrm{mg} \cdot \mathrm{kg}^{-1}$ d.m.; PL2: $12.28 \mathrm{mg} \cdot \mathrm{kg}^{-1}$ d.m.; PL3: $13.37 \mathrm{mg} \cdot \mathrm{kg}^{-1}$ d.m.) and $\mathrm{Pb}$ up to 257.90 mg $\cdot \mathrm{kg}^{-1}$ d.m. (PL1: $257.90 \mathrm{mg} \cdot \mathrm{kg}^{-1} \mathrm{~d} . \mathrm{m}$.; PL2: $197.02 \mathrm{mg} \cdot \mathrm{kg}^{-1}$ d.m.; PL3: $197.95 \mathrm{mg} \cdot \mathrm{kg}^{-1}$ d.m.). The water extract contained a big quantity of sulphates $\left(\mathrm{SO}_{4}^{2-}\right)$ : PL1: $6,980.00 \mathrm{mg} \cdot \mathrm{dm}^{-3}$; PL2: 7,710.00 $\mathrm{mg} \cdot \mathrm{dm}^{-3}$; PL3: $8,480.00 \mathrm{mg} \cdot \mathrm{dm}^{-3}$, and chlorides (Cl-): PL1: $1,416.00 \mathrm{mg}^{-} \mathrm{dm}^{-3}$; PL2: $102.10 \mathrm{mg} \cdot \mathrm{dm}^{-3}$; PL3: $1,094.00 \mathrm{mg} \cdot \mathrm{dg}^{-3}$. The water extract also contained e.g. the following ions: $\mathrm{K}^{+}$up to $10,320 \mathrm{mg} \cdot \mathrm{dm}^{-3}, \mathrm{Na}^{+}$up to $108 \mathrm{mg} \cdot \mathrm{dm}^{-3}$, and $\mathrm{Ca}^{2+}$ up to $630.80 \mathrm{mg} \cdot \mathrm{dm}^{-3}$.

\section{Physical and chemical properties of bottom ash (PD)}

The bottom ash (PD) was dominated by sand fraction (PD1: 94.9\%; PD2: 97.2\%; PD3: 96.0\%), with the dust fraction proportion (PD1: $0.4 \%$; PD2: $0.2 \%$; PD3: $1.1 \%$ ). The water extract reaction ranged from $\mathrm{pH}=9.98$ to $\mathrm{pH}=11.69$, depending on individual samples. The water extract was classified either as sulphate-hydroxy-potassium water or potassium-calcium-sulphate-hydroxy water (depending on the sample).

The bottom ash generated by biomass combustion was characterised by a high $\mathrm{SiO}_{2}$ content $(>75 \%)$. We should mention especially the high content of mineral components that are indispensable for plants, e.g.: $\mathrm{K}$ up to $16.19 \mathrm{~g} \cdot \mathrm{kg}^{-1}$ d.m. (PD1: $15.25 \mathrm{~g} \cdot \mathrm{kg}^{-1}$ d.m.; PD2: $14.14 \mathrm{~g} \cdot \mathrm{kg}^{-1}$ d.m.; PD3: $16.19 \mathrm{~g} \cdot \mathrm{kg}^{-1}$ d.m.), Ca up to $32.92 \mathrm{~g} \cdot \mathrm{kg}^{-1}$ d.m. (PD1: $32.92 \mathrm{~g} \cdot \mathrm{kg}^{-1}$ d.m.; PD2: $20.28 \mathrm{~g} \cdot \mathrm{kg}^{-}$ ${ }^{1}$ d.m.; PD3: $25.62 \mathrm{~g} \cdot \mathrm{kg}^{-1}$ d.m.), $\mathrm{Mg}$ up to 8.65 $\mathrm{g} \cdot \mathrm{kg}^{-1}$ d.m. (PD1: $8.65 \mathrm{~g} \cdot \mathrm{kg}^{-1}$ d.m.; PD2: 6.24 $\mathrm{g} \cdot \mathrm{kg}^{-1}$ d.m.; PD3: $6.70 \mathrm{~g} \cdot \mathrm{kg}^{-1}$ d.m.), P up to 11.75 $\mathrm{g} \cdot \mathrm{kg}^{-1}$ d.m. (PD1: $11.75 \mathrm{~g} \cdot \mathrm{kg}^{-1}$ d.m.; PD2: 5.13 $\mathrm{g} \cdot \mathrm{kg}^{-1}$ d.m.; PD3: $4.43 \mathrm{~g} \cdot \mathrm{kg}^{-1}$ d.m.), and Mn up to $1.25 \mathrm{~g} \cdot \mathrm{kg}^{-1}$ d.m. (PD1: $0.96 \mathrm{~g} \cdot \mathrm{kg}^{-1}$ d.m.; PD2: $0.59 \mathrm{~g} \cdot \mathrm{kg}^{-1}$ d.m.; PD3: $1.25 \mathrm{~g} \cdot \mathrm{kg}^{-1}$ d.m.). Bottom ash also contained small quantities of heavy metals such as $\mathrm{Pb}, \mathrm{Cd}$, and $\mathrm{Hg}$. Sulphates $\left(\mathrm{SO}_{4}^{2-}\right.$ ) concentration ranged from 214.90 to 509.90 $\mathrm{mg} \cdot \mathrm{dm}^{-3}$ (PD1: $214.90 \mathrm{mg} \cdot \mathrm{dm}^{-3}$; PD2: 236.90 $\mathrm{mg} \cdot \mathrm{dm}^{-3}$; PD3: $\left.509.90 \mathrm{mg} \cdot \mathrm{dm}^{-3}\right)$, while chlorides from 6.8 to $44.1 \mathrm{mg} \cdot \mathrm{dm}^{-3}$ (PD1: $22.00 \mathrm{mg} \cdot \mathrm{dmg}^{-3}$; PD2: $6.80 \mathrm{mg} \cdot \mathrm{dm}^{-3} \mathrm{~d} . \mathrm{m}$.; PD3: $44.10 \mathrm{mg} \cdot \mathrm{dm}^{-3}$ ) in the water extract.

\section{Evaluation of the influence of waste on seed germination}

Our experiments with test plants revealed the existence of different reactions of particular plant species to fly ash or bottom ash addition to soil substrate in the majority of cases.

The addition of two different doses of fly ash to the universal substrate: $10 \%$ and $30 \%$, caused complete suppression of germination of the white mustard seed in all the experimental specimens. In the case of red fescue (Festuca rubra), no seed germination was observed after 7 days, followed by a couple of them (1-2) germinating in all the experimental groups with the $10 \%$ content of fly ash in the substrate after 10 days. The addition of $30 \%$ of fly ash caused complete suppression of seed germination.

The addition of $10 \%$ of bottom ash to the substrate positively influenced white mustard seed (Sinapis alba) germination. However, a bigger share of waste in the substrate $(30 \%)$ caused reduction of the number of germinated seeds, in comparison to that of the control group (ktr). Figure 1 shows the proportions of germinated seeds as average values for three repetitions after 3 days since seeding.

In the case of the red fescue (Festuca rubra), the addition of $10 \%$ of bottom ash (PD) to the substrate caused faster seed germination, in comparison to that of the control group (ktr) (Fig. 2).

A high percentage of germinated seeds appeared after 7 days. However, after 10 days of observation, the rate was equalised and the proportions of germinated seeds were similar in all the experimental groups (Fig. 3).

\section{Evaluation of the influence of the tested waste on the growth of shoots and roots}

The proportion of fly ash contained in the substrate essentially limited the growth of the Sinapis alba in the test groups with a $10 \%$ addition of waste (Fig. 4). However, a 30\% share of fly ash completely suppressed the plant growth, in comparison to that of the control plant development.

It was also found that the addition of fly ash originating from various samples (PL1, PL2, and PL3) caused various reactions in plants (Fig. 5). 


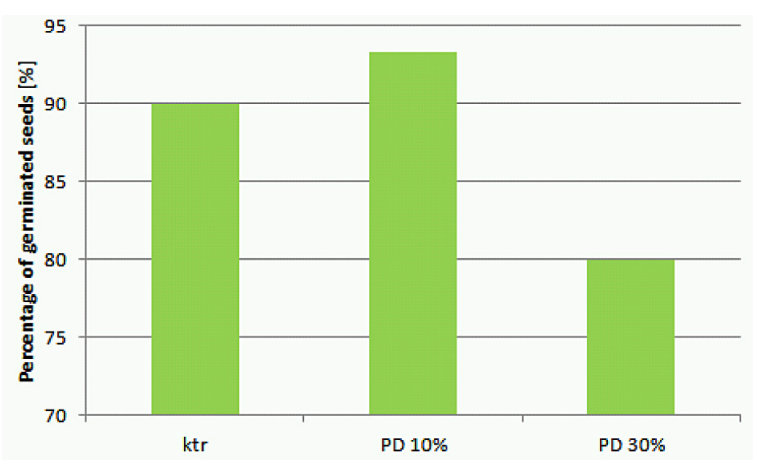

Fig. 1. The percentage of germinated Sinapis alba seeds on Day 3 of the experiment; substrate with bottom ash

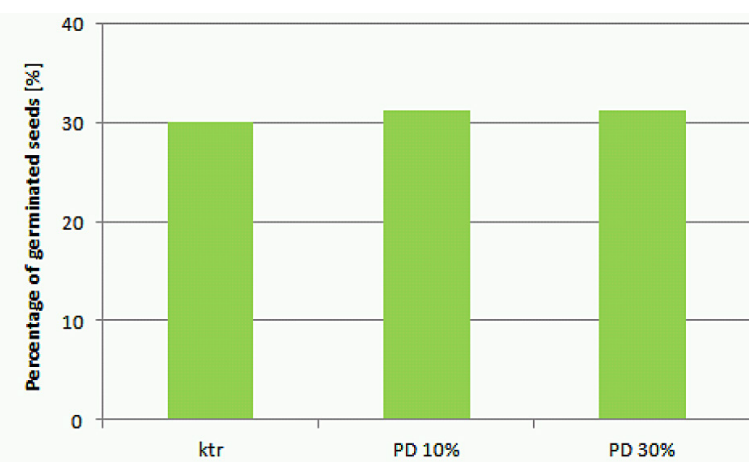

Fig. 3. The percentage of germination (Festuca rubra) on the 10th day of the experiment(values for the three samples in three repetitions)

The white mustard seed grown on the substrate with the addition of bottom ash, originating from biomass combustion (PD 10\%), was characterised by a similar growth of the shoots $(\mathrm{Z})$ and roots $(\mathrm{K})$, in comparison to those of the control group plants. The addition of $30 \%$ of bottom ash

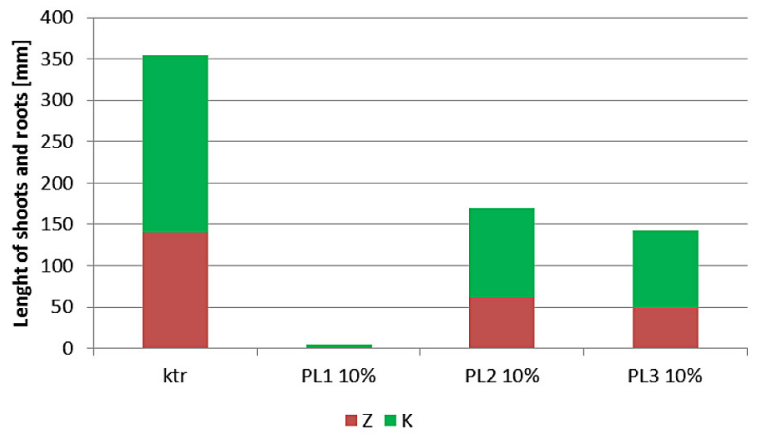

Fig. 5. The total growth of the shoots $(Z)$ and roots $(\mathrm{K})$ of the Sinapis alba on the 7th day of the experiment on the substrates with a $10 \%$ addition of fly ash in individual experimental specimens (PL1, PL2, PL3)

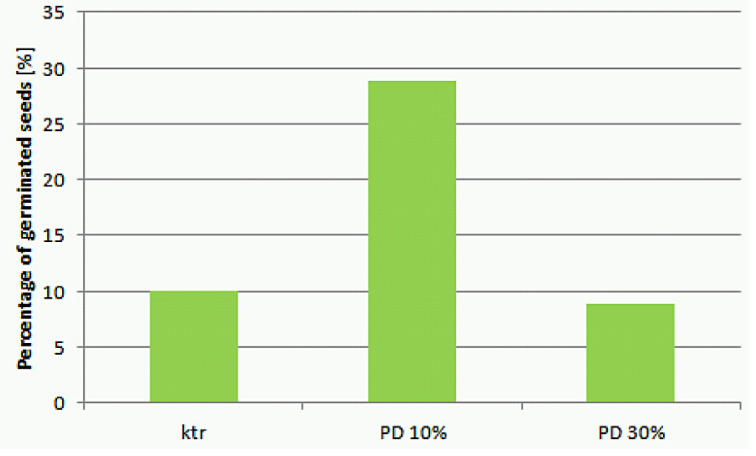

Fig. 2. The percentage of germination (Festuca rubra) on the 7th day of the experiment (values for the three samples in three repetitions); substrate with bottom ash

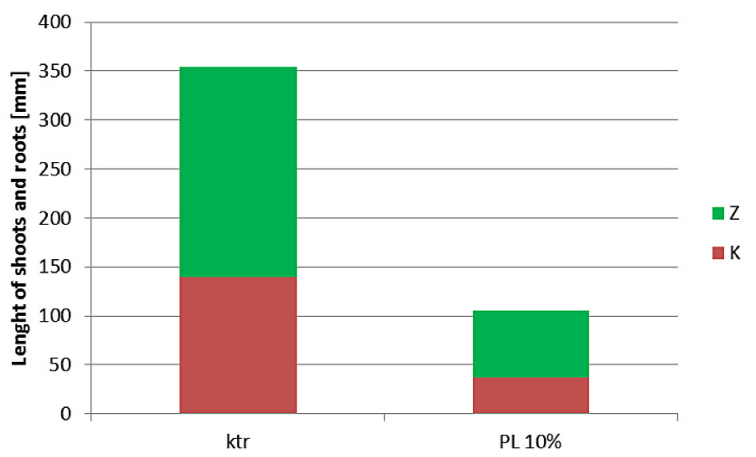

Fig. 4. The total growth of the shoots $(\mathrm{Z})$ and roots (K) of the Sinapis alba on the 7th day of the experiment on the substrates with a $10 \%$ addition of fly ash (averaged values for three repetitions)

(PD) to the universal substrate caused a reduction of the plant growth (Fig. 6).

The growth of the shoots and roots was different in the plants belonging to different experimental specimens, even when we applied the same type of waste (after combusting the same

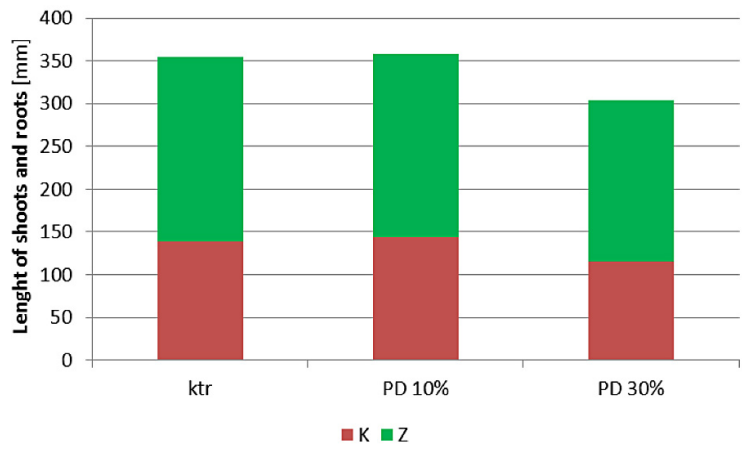

Fig. 6. The total growth of the shoots $(\mathrm{Z})$ and roots (K) of the Sinapis alba on the 7th day of the experiment on the substrates with a $10 \%$ and $30 \%$ addition of bottom ash (averaged values for three repetitions) 
kind of biomass), collected from the same installation but in various months (bottom ash: samples PD1, PD2, and PD3; fly ash: samples PL1, PL2, and PL3), see Figs. 5, 7, and 11.

To evaluate whether the differences of the shoots and roots growth in particular test groups were essential, the Mann-Whitney U tests were carried out, assuming lack of differences between the groups, as a zero hypothesis. The test results are presented in Tables 1 and 2.

The addition of fly ash to the universal substrate, in the proportions of $10 \%$ and $30 \%$, limited the development of plants also in the case of the red fescue (Fig. 8).

The other test species (Festuca rubra) demonstrated a positive reaction to the addition of bottom ash (PD) to the substrate, in the proportions of 10 and $30 \%$; however, the growth of the plants in the specimens with a $10 \%$ of PD addition was by $35 \%$ higher in comparison to that of the control specimens, while in the groups with a $30 \%$ addition of PD, the growth was comparable to that of the reference specimens (Fig. 10).

The reactions of the plants to the addition of waste, originating from various samples (collected in various months), to the substrate, were essentially different between the experimental specimen groups (PD1, PD2, and PD3), similarly to those of the Sinapis alba test plants (Figs. 11-13).

To evaluate whether the growth differences of the shoots of the red fescue in particular test groups were essential, the Mann-Whitney U tests were carried out, assuming lack of differences between the groups, as a zero hypothesis. The test results are presented in Table 3.

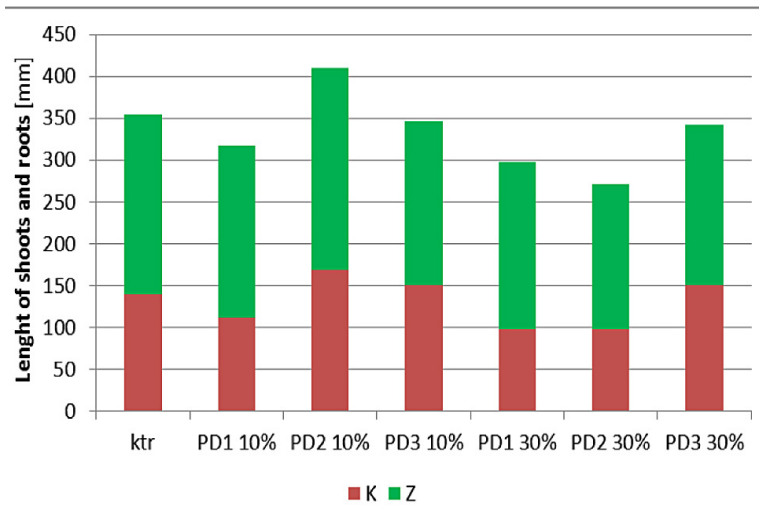

Fig. 7. The total growth of the shoots (Z) and roots (K) of the Sinapis alba on the 7 th day of the experiment on the substrates with a $10 \%$ and $30 \%$ addition of bottom ash in particular experimental specimens

\section{CONCLUSIONS}

The purpose of the completed experiments was to determine the influence of waste on the test plants and the possibilities of waste use in the environment. Our preliminary tests demonstrated various kinds of the influence of specific wastes on the plant growth and development. The results of experiments indicated certain options of using the tested bottom ash, originating from biomass combustion, in the environment and a limited option of a similar use of fly ash collected from the specific installation.

The reactions of the plants depended on the share of the tested bottom ash in the substrate:

1. A $10 \%$ percentage of the bottom ash was beneficial for the seed germination and test plant development.

2. In the case of the substrates with a $30 \%$ proportion of the bottom ash, a reduction of the plant growth in comparison to that of control plants was observed. The reaction of the plants also depended on individual samples of wastes and on the differentiation of biomass (samples were collected at different dates, but they differed in properties, in each case the type of combusted biomass was the same).

3. The addition of the fly ash to the substrate caused suppression of seed germination and plant growth of both types of test species. However, that effect does not exclude a possibility of using that type of waste in soil when is applied a lower proportion of waste in substrate (further tests are required in that case).

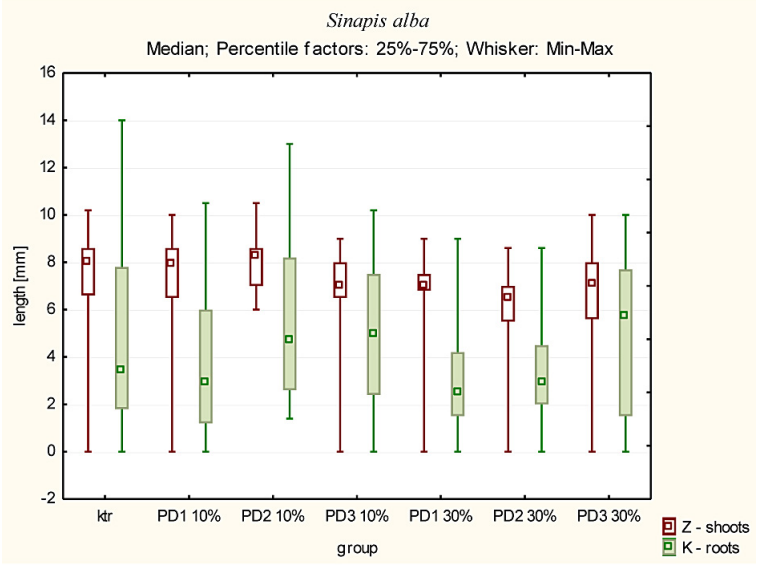

Fig. 8. The growth of the Sinapis alba on the 7th day of the experiment on the substrates with a $10 \%$ and $30 \%$ addition of bottom ash in particular experimental specimens 
Table 1. The results of the Mann-Whitney U tests of the growth of the shoots (H0 - no essential differences between the groups, $\mathrm{H} 1$ - there are essential differences between the groups)

\begin{tabular}{|c|c|c|c|c|c|c|c|c|c|c|c|c|}
\hline & $\begin{array}{l}\text { PD } 1 \\
10 \% \\
\end{array}$ & $\begin{array}{l}\text { PD } 2 \\
10 \% \\
\end{array}$ & $\begin{array}{l}\text { PD } 3 \\
10 \% \\
\end{array}$ & $\begin{array}{l}\text { PD } 1 \\
30 \% \\
\end{array}$ & $\begin{array}{l}\text { PD } 2 \\
30 \% \\
\end{array}$ & $\begin{array}{l}\text { PD } 3 \\
30 \%\end{array}$ & $\begin{array}{l}\mathrm{PL} 1 \\
10 \% \\
\end{array}$ & $\begin{array}{l}\mathrm{PL} 2 \\
10 \% \\
\end{array}$ & $\begin{array}{l}\mathrm{PL} 3 \\
10 \% \\
\end{array}$ & $\begin{array}{l}\mathrm{PL} 1 \\
30 \%\end{array}$ & $\begin{array}{l}\mathrm{PL} 2 \\
30 \% \\
\end{array}$ & $\begin{array}{l}\text { PL } 3 \\
30 \% \\
\end{array}$ \\
\hline Control & $\mathrm{HO}$ & $\mathrm{HO}$ & $\mathrm{H} 1$ & $\mathrm{H} 1$ & $\mathrm{H} 1$ & $\mathrm{HO}$ & $\mathrm{H} 1$ & $\mathrm{H} 1$ & $\mathrm{H} 1$ & $\mathrm{H} 1$ & $\mathrm{H} 1$ & $\mathrm{H} 1$ \\
\hline PD 1 10\% & & $\mathrm{HO}$ & $\mathrm{HO}$ & $\mathrm{H} 1$ & $\mathrm{H} 1$ & $\mathrm{HO}$ & $\mathrm{H} 1$ & $\mathrm{H} 1$ & $\mathrm{H} 1$ & $\mathrm{H} 1$ & $\mathrm{H} 1$ & $\mathrm{H} 1$ \\
\hline PD 2 10\% & & & $\mathrm{H} 1$ & $\mathrm{H} 1$ & $\mathrm{H} 1$ & $\mathrm{H} 1$ & $\mathrm{H} 1$ & $\mathrm{H} 1$ & $\mathrm{H} 1$ & $\mathrm{H} 1$ & $\mathrm{H} 1$ & $\mathrm{H} 1$ \\
\hline PD 3 10\% & & & & $\mathrm{HO}$ & $\mathrm{H} 1$ & $\mathrm{HO}$ & $\mathrm{H} 1$ & $\mathrm{H} 1$ & $\mathrm{H} 1$ & $\mathrm{H} 1$ & $\mathrm{H} 1$ & $\mathrm{H} 1$ \\
\hline PD $130 \%$ & & & & & $\mathrm{H} 1$ & $\mathrm{HO}$ & $\mathrm{H} 1$ & $\mathrm{H} 1$ & $\mathrm{H} 1$ & $\mathrm{H} 1$ & $\mathrm{H} 1$ & $\mathrm{H} 1$ \\
\hline PD $230 \%$ & & & & & & $\mathrm{HO}$ & $\mathrm{H} 1$ & $\mathrm{H} 1$ & $\mathrm{H} 1$ & $\mathrm{H} 1$ & $\mathrm{H} 1$ & $\mathrm{H} 1$ \\
\hline PD $330 \%$ & & & & & & & $\mathrm{H} 1$ & $\mathrm{H} 1$ & $\mathrm{H} 1$ & $\mathrm{H} 1$ & $\mathrm{H} 1$ & $\mathrm{H} 1$ \\
\hline PL $110 \%$ & & & & & & & & $\mathrm{H} 1$ & $\mathrm{H} 1$ & $\mathrm{H} 1$ & $\mathrm{H} 1$ & $\mathrm{H} 1$ \\
\hline PL 2 10\% & & & & & & & & & $\mathrm{HO}$ & $\mathrm{H} 1$ & $\mathrm{H} 1$ & $\mathrm{H} 1$ \\
\hline PL 3 10\% & & & & & & & & & & $\mathrm{H} 1$ & $\mathrm{H} 1$ & $\mathrm{H} 1$ \\
\hline PL $130 \%$ & & & & & & & & & & & $\mathrm{HO}$ & $\mathrm{HO}$ \\
\hline PL $230 \%$ & & & & & & & & & & & & $\mathrm{HO}$ \\
\hline
\end{tabular}

Table 2. The results of the Mann-Whitney U tests of the growth of the roots ( $\mathrm{H} 0$ - no essential differences between the groups, $\mathrm{H} 1$ - there are essential differences between the groups)

\begin{tabular}{|c|c|c|c|c|c|c|c|c|c|c|c|c|}
\hline & $\begin{array}{l}\text { PD } 1 \\
10 \%\end{array}$ & $\begin{array}{l}\text { PD } 2 \\
10 \%\end{array}$ & $\begin{array}{l}\text { PD } 3 \\
10 \%\end{array}$ & $\begin{array}{l}\text { PD } 1 \\
30 \%\end{array}$ & $\begin{array}{l}\text { PD } 2 \\
30 \%\end{array}$ & $\begin{array}{l}\text { PD } 3 \\
30 \%\end{array}$ & $\begin{array}{l}\text { PL 1 } \\
10 \%\end{array}$ & $\begin{array}{l}\text { PL } 2 \\
10 \%\end{array}$ & $\begin{array}{l}\text { PL } 3 \\
10 \%\end{array}$ & $\begin{array}{l}\mathrm{PL} 1 \\
30 \%\end{array}$ & $\begin{array}{l}\text { PL } 2 \\
30 \%\end{array}$ & $\begin{array}{l}\text { PL } 3 \\
30 \%\end{array}$ \\
\hline Control & $\mathrm{HO}$ & $\mathrm{HO}$ & $\mathrm{HO}$ & $\mathrm{HO}$ & $\mathrm{HO}$ & $\mathrm{HO}$ & $\mathrm{H} 1$ & $\mathrm{H} 1$ & $\mathrm{H} 1$ & $\mathrm{H} 1$ & $\mathrm{H} 1$ & $\mathrm{H} 1$ \\
\hline PD $110 \%$ & & $\mathrm{H} 1$ & $\mathrm{HO}$ & $\mathrm{HO}$ & $\mathrm{HO}$ & $\mathrm{HO}$ & $\mathrm{H} 1$ & $\mathrm{H} 1$ & $\mathrm{H} 1$ & $\mathrm{H} 1$ & $\mathrm{H} 1$ & $\mathrm{H} 1$ \\
\hline PD 2 10\% & & & HO & $\mathrm{H} 1$ & H1 & HO & $\mathrm{H} 1$ & $\mathrm{H} 1$ & H1 & $\mathrm{H} 1$ & $\mathrm{H} 1$ & $\mathrm{H} 1$ \\
\hline PD 3 10\% & & & & $\mathrm{H} 1$ & $\mathrm{H} 1$ & $\mathrm{HO}$ & $\mathrm{H} 1$ & $\mathrm{H} 1$ & $\mathrm{H} 1$ & $\mathrm{H} 1$ & $\mathrm{H} 1$ & $\mathrm{H} 1$ \\
\hline PD $130 \%$ & & & & & $\mathrm{HO}$ & $\mathrm{HO}$ & $\mathrm{H} 1$ & $\mathrm{HO}$ & $\mathrm{H} 1$ & $\mathrm{H} 1$ & $\mathrm{H} 1$ & $\mathrm{H} 1$ \\
\hline PD $230 \%$ & & & & & & $\mathrm{H} 1$ & $\mathrm{H} 1$ & $\mathrm{H} 1$ & $\mathrm{H} 1$ & $\mathrm{H} 1$ & $\mathrm{H} 1$ & $\mathrm{H} 1$ \\
\hline PD $330 \%$ & & & & & & & $\mathrm{H} 1$ & $\mathrm{H} 1$ & $\mathrm{H} 1$ & $\mathrm{H} 1$ & $\mathrm{H} 1$ & $\mathrm{H} 1$ \\
\hline PL $110 \%$ & & & & & & & & $\mathrm{H} 1$ & $\mathrm{H} 1$ & $\mathrm{HO}$ & $\mathrm{HO}$ & $\mathrm{HO}$ \\
\hline PL 2 10\% & & & & & & & & & $\mathrm{HO}$ & $\mathrm{H} 1$ & $\mathrm{H} 1$ & $\mathrm{H} 1$ \\
\hline PL 3 10\% & & & & & & & & & & $\mathrm{H} 1$ & $\mathrm{H} 1$ & $\mathrm{H} 1$ \\
\hline PL $130 \%$ & & & & & & & & & & & $\mathrm{HO}$ & $\mathrm{HO}$ \\
\hline PL $230 \%$ & & & & & & & & & & & & $\mathrm{HO}$ \\
\hline
\end{tabular}

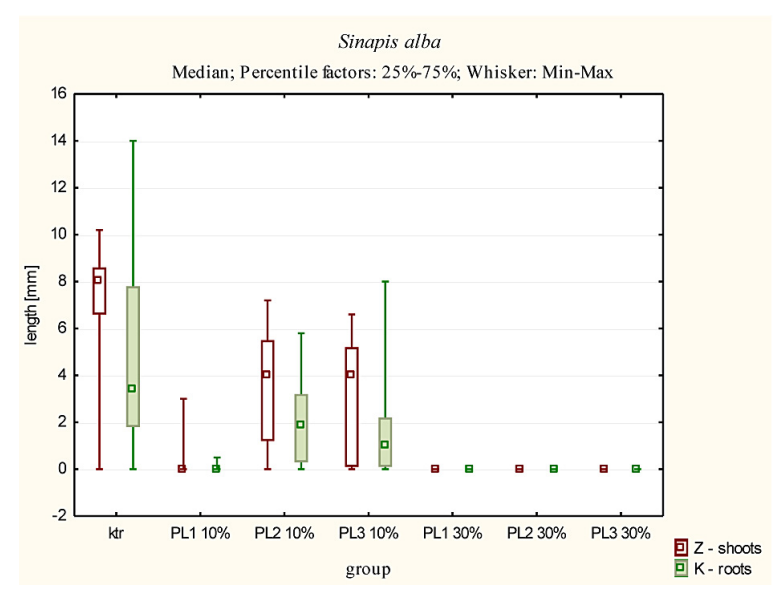

Fig. 9. The growth of the Sinapis alba on the 7th day of the experiment on the substrates with a $10 \%$ and $30 \%$ addition of fly ash in particular experimental specimens
4. The observed reactions of the plants might be influenced by the contents of sulphates in ash, which is the effect of the application of corrosion protection substances on the surfaces of the heated portions of power-generation boilers in the power plant from which waste samples were collected for these experiments.

5. The high $\mathrm{pH}$ value of fly ash could also be the factor that influenced the reactions of the test plants.

The direction and range of using the powergeneration waste, originating from the biomass combustion in a fluidised-bed boiler (fly ash and bottom ash) are strictly dependent on the chemical properties of waste, which are highly changeable in time, in respect of both beneficial and 


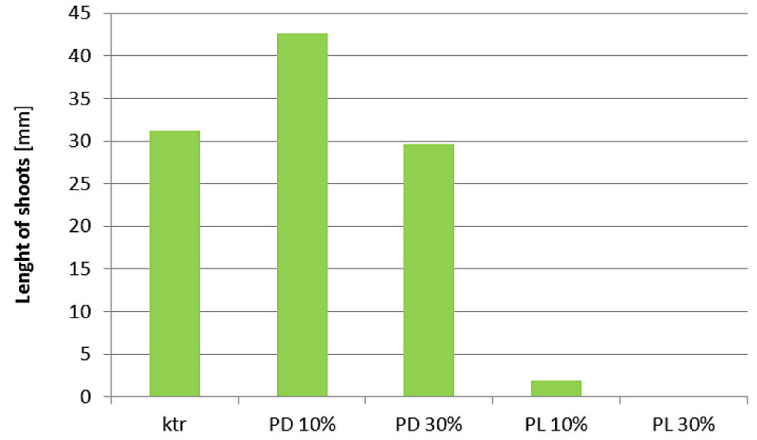

Fig. 10. The total growth of the shoots of the Festuca rubra on the 14th day of the experiment on the substrates with a $10 \%$ and $30 \%$ addition of fly ash (PL) and bottom ash (PD)

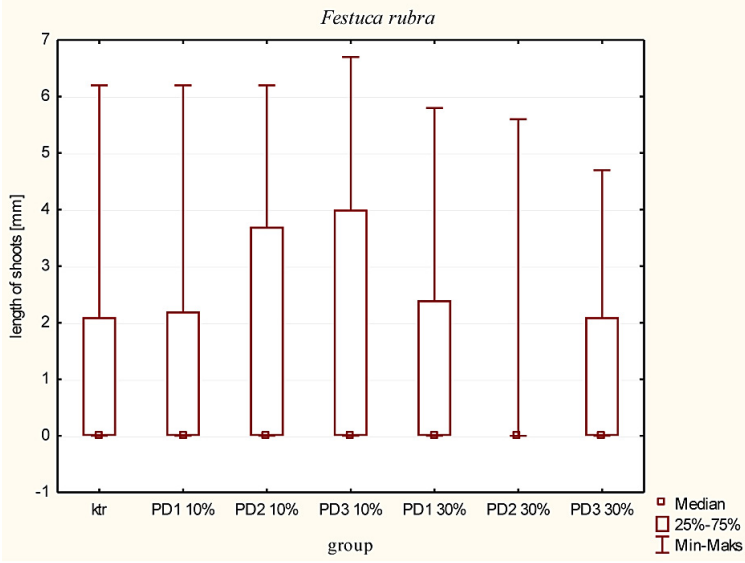

Fig. 12. The growth of the Festuca rubra on the 14th day of the experiment on the substrates with a $10 \%$ and $30 \%$ addition of bottom ash (PD) in particular experimental specimens

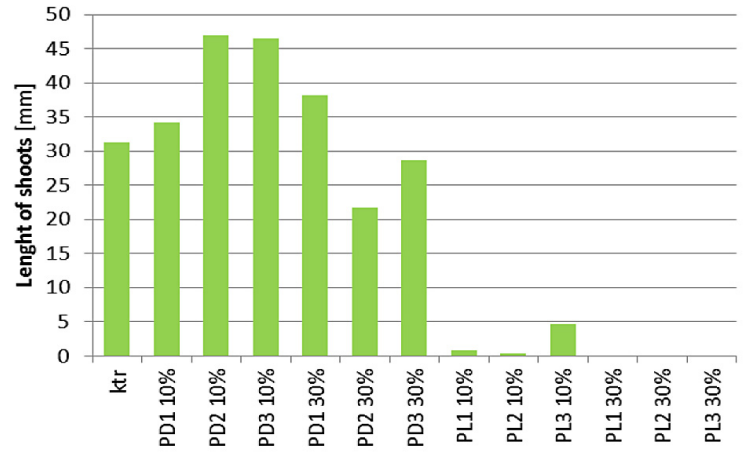

Fig. 11. The total growth of the Festuca rubra on the 14 th day of the experiment on the substrates with a $10 \%$ and $30 \%$ addition of fly ash (PL) and bottom ash (PD) in particular experimental specimens

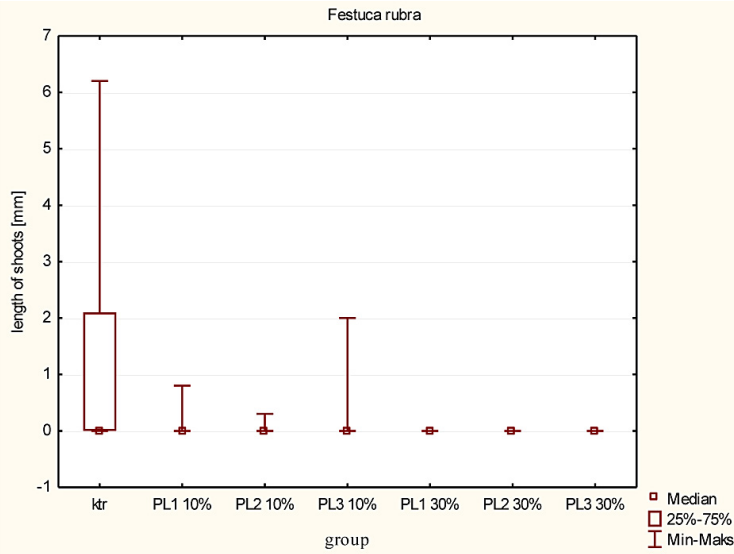

Fig. 13. The growth rate of the Festuca rubra on the 14th day of the experiment on the substrates with a $10 \%$ and $30 \%$ addition of fly ash (PL) in particular experimental specimens

Table 3. The results of the Mann-Whitney U tests of the growth of the roots ( $\mathrm{H} 0$ - no essential differences between the groups, $\mathrm{H} 1$ - there are essential differences between the groups)

\begin{tabular}{|c|c|c|c|c|c|c|c|c|c|c|c|c|}
\hline & $\begin{array}{l}\text { PD } 1 \\
10 \%\end{array}$ & $\begin{array}{l}\text { PD } 2 \\
10 \%\end{array}$ & $\begin{array}{l}\text { PD } 3 \\
10 \%\end{array}$ & $\begin{array}{l}\text { PD } 1 \\
30 \%\end{array}$ & $\begin{array}{l}\text { PD } 2 \\
30 \%\end{array}$ & $\begin{array}{l}\text { PD } 3 \\
30 \%\end{array}$ & $\begin{array}{l}\mathrm{PL} 1 \\
10 \%\end{array}$ & $\begin{array}{l}\text { PL } 2 \\
10 \%\end{array}$ & $\begin{array}{l}\text { PL } 3 \\
10 \%\end{array}$ & $\begin{array}{l}\text { PL } 1 \\
30 \%\end{array}$ & $\begin{array}{l}\text { PL } 2 \\
30 \%\end{array}$ & $\begin{array}{l}\text { PL } 3 \\
30 \%\end{array}$ \\
\hline Control & $\mathrm{H} 0$ & $\mathrm{HO}$ & $\mathrm{HO}$ & $\mathrm{HO}$ & $\mathrm{H} 0$ & $\mathrm{HO}$ & $\mathrm{H} 1$ & $\mathrm{H} 1$ & $\mathrm{H} 1$ & $\mathrm{H} 1$ & $\mathrm{H} 1$ & $\mathrm{H} 1$ \\
\hline PD 1 10\% & & $\mathrm{HO}$ & $\mathrm{HO}$ & $\mathrm{HO}$ & $\mathrm{HO}$ & $\mathrm{HO}$ & $\mathrm{H} 1$ & $\mathrm{H} 1$ & $\mathrm{H} 1$ & $\mathrm{H} 1$ & $\mathrm{H} 1$ & $\mathrm{H} 1$ \\
\hline PD 2 10\% & & & $\mathrm{HO}$ & $\mathrm{HO}$ & $\mathrm{HO}$ & $\mathrm{HO}$ & $\mathrm{H} 1$ & $\mathrm{H} 1$ & $\mathrm{H} 1$ & $\mathrm{H} 1$ & $\mathrm{H} 1$ & $\mathrm{H} 1$ \\
\hline PD $310 \%$ & & & & $\mathrm{H} 0$ & $\mathrm{HO}$ & $\mathrm{HO}$ & $\mathrm{H} 1$ & $\mathrm{H} 1$ & $\mathrm{H} 1$ & $\mathrm{H} 1$ & $\mathrm{H} 1$ & $\mathrm{H} 1$ \\
\hline PD $130 \%$ & & & & & $\mathrm{HO}$ & $\mathrm{H} 0$ & $\mathrm{H} 1$ & $\mathrm{H} 1$ & $\mathrm{H} 1$ & $\mathrm{H} 1$ & $\mathrm{H} 1$ & $\mathrm{H} 1$ \\
\hline PD $230 \%$ & & & & & & $\mathrm{HO}$ & $\mathrm{H} 1$ & $\mathrm{H} 1$ & $\mathrm{HO}$ & $\mathrm{H} 1$ & $\mathrm{H} 1$ & $\mathrm{H} 1$ \\
\hline PD $330 \%$ & & & & & & & $\mathrm{H} 1$ & $\mathrm{H} 1$ & $\mathrm{HO}$ & $\mathrm{H} 1$ & $\mathrm{H} 1$ & $\mathrm{H} 1$ \\
\hline PL 1 10\% & & & & & & & & $\mathrm{HO}$ & $\mathrm{H} 0$ & $\mathrm{HO}$ & $\mathrm{HO}$ & $\mathrm{HO}$ \\
\hline PL 2 10\% & & & & & & & & & $\mathrm{H} 0$ & $\mathrm{HO}$ & $\mathrm{HO}$ & $\mathrm{H} 0$ \\
\hline PL $310 \%$ & & & & & & & & & & $\mathrm{HO}$ & $\mathrm{HO}$ & $\mathrm{HO}$ \\
\hline PL $130 \%$ & & & & & & & & & & & $\mathrm{HO}$ & $\mathrm{H} 0$ \\
\hline PL $230 \%$ & & & & & & & & & & & & $\mathrm{HO}$ \\
\hline
\end{tabular}

undesired (e.g. $\mathrm{SO}_{3}$ ) elements affecting the plant growth. The instability of waste properties, especially of the chemical parameters of the tested waste, was confirmed by our chemical analyses carried out on each of the samples collected from the same installation but in various months. For 
that reason, a thorough chemical analysis is required before waste is introduced to soil.

\section{Acknowledgements}

This study was conducted under statutory research of the Department of Environmental Engineering and Mineral Processing (Project No. 11.11.100.482), Faculty of Mining and Geoengineering, AGH University of Science and Technology in Kraków, Poland.

\section{REFERENCES}

1. Ahmaruzzaman M. 2010. A review on the utilization of fly ash. Progress in Energy and Combustion Science, 36, 327-363.

2. Antonkiewicz J. 2009. Wykorzystanie popiołów paleniskowych do wiązania metali ciężkich występujących w glebie. Ochrona Środowiska i Zasobów Naturalnych, 41, 398- 405.

3. Baran A., Śliwka M., Lis M. 2013. Selected properties of flotation tailings wastes deposited in the Gilów and Żelazny Most waste reservoirs regarding their potential environmental management. Archives of Mining Sciences, 58 (3), 969-978.

4. Berra M., Mangialardi T., Paolini A.E. 2015. Reuse of woody biomass fly ash in cement-based materials. Construction and Building Materials, 76, 286-296.

5. Bielińska E.J., Baran St., Stankowski S. 2009. Ocena przydatności popiołów fluidalnych z węgla kamiennego do celów rolniczych. Inżynieria rolnicza, 6 (15), 7-15.

6. Ciećko Z., Żołnowski A.C., Chełstowski A. 2007. Wpływ następczy popiołów z węgla kamiennego na skład chemiczny runi łąkowej. Zeszyty Problemowe Postępów Nauk Rolniczych, 518, 23-33.

7. Cuenca J., Rodriguez J., Martin-Morales M., Sanchez-Roldan, Zamorano M. 2013. Effects of olive residue biomass fly ash as filler in self-compacting concrete. Construction and Building Materials, 40, 702-709.

8. Czech T., Gambuś F., Wieczorek J. 2013. Assessment of chemical composition of waste materials from hard coal burning in view of their agricultural and environmental applications. Inżynieria Ekologiczna, 34, 89-95.

9. Dyguś K.H., Siuta J., Wasiak G., Madej M. 2012. Roślinność składowisk odpadów komunalnych i przemysłowych. Monografia, Warszawa. Wyd. Wyższa Szkoła Ekologii i Zarządzania.

10. Gawlicki M., Graur Z., Ślęzak E. 2014. Popioły lotne ze spalania biomasy jako składnik spoiw drogowych. Prace Instytutu Ceramiki i Materiałów Budowlanych, 19, 34- 46.

11. Grammelis P., Skodras G., Kakaras E. 2006. Effects of biomass co-firing with coal on ash properties. Part I: Characterisation and PSD. Fuel, 85, 2310-2315.

12. James R.W., Thring S., Helle H.S., Ghuman H.S. 2012. Ash management review-applications of biomass bottom ash. Energies, 5, 3856-3873.

13. Góral S. 2001. Roślinność zielna w ochronie i rekultywacji gruntów. Inżynieria ekologiczna, 3, 161-178.

14. Góral S., Rola S. 2001. Trawy na popiołach elektrociepłowni nawożonych osadami ściekowymi. Inżynieria Ekologiczna, 3, 146-150.

15. Kabata-Pendias A., Pendias H. 1999. Biogeochemia pierwiastków śladowych. Warszawa, Wyd. PWN.

16. Kępys W., Pomykała R. 2014. Research into the Usefulness of Ash from the Co-Combustion of Lignite and Biomass in Mining Technologies. Polish Journal of Environmental Studies, 23 (4), 1381-1384.

17. Kępys W., Piotrowski Z., Pomykała R., Grzywa A. 2014. Application of Fly Ash from Biomass in Suspension Technologies. Inżynieria Mineralna, 15 (2), 251-255.

18. Kopcewicz J., Lewak S. 2007. Fizjologia roślin. Warszawa. Wyd. Nauk. PWN.

19. Kostecka J. 2013. Self-evaluation on the way to retardation of pace life and resources transformation. Problemy Ekorozwoju, 8 (2), 93-102.

20. Kostecka J., Koc-Jurczyk J. 2010. Odpady niebezpieczne a problem retardacji przekształcenia zasobów przyrodniczych. Biuletyn Komitetu Przestrzennego Zagospodarowania Kraju PAN, 242, 168-185.

21. Lima A.T., Ottosen L.M., Pedersen A.J., Ribeiro A.B. 2008. Characterization of fly ash from bio and municipal waste. Biomass Bioenergy, 32 (3), 277-282.

22. PN-EN 12457-2 Charakteryzowanie odpadów - Wymywanie - Badanie zgodności w odniesieniu do wymywania ziarnistych materiałów odpadowych i osadów - Część 2: Jednostopniowe badanie porcjowe przy stosunku cieczy do fazy stałej $101 / \mathrm{kg} \mathrm{w}$ przypadku materiałów o wielkości cząstek poniżej $4 \mathrm{~mm}$ (bez redukcji lub z redukcją wielkości).

23. Poluszyńska J. 2013. Możliwości zastosowania popiołów ze spalania biomasy $\mathrm{w}$ gospodarowaniu osadami ściekowymi. Prace Instytutu Ceramiki i Materiałów Budowlanych, 13, 49-59.

24. Pomykała R., Kępys W., Piotrowski Z., Łyko P., Grzywa P. 2015. The Temperature Influence On 
The Properties Of The Fine - Grained Suspension Used In Underground Workings. Archives of Mining Sciences, 60 (4), 1053-1070.

25. Pomykała R., Mazurkiewicz M. 2015. Properties of coal gasification wastes essential to determining their impact on the environment. Polish Journal of Environmental Studies, 24 (5), 2147-2155.

26. Portal Krajowego Forum Spalania Biomasy: www. spalaniebiomasy.pl (dostęp: 30.09.2016)

27. Rajamma R., Ball R.J., Tarelho L.A.C., Allen G.C., Labrincha J.A., Ferreira V.M. 2009. Characterisation and use of biomass fly ash in cement-based materials. Journal of Hazardous Materials, 172, 1049-1060.

28. Rosik-Dulewska Cz. 2015. Podstawy gospodarki odpadami. Wyd. Nauk. PWN, Warszawa.

29. Stankowski S., Hury G., Gibczyńska M., JurgielMałecka G. 2014. Wpływ stosowania wapna, popiołu z biomasy i kompostu oraz preparatu EM na plonowanie i komponenty plonu pszenicy. Inżynieria Ekologiczna, 38, 17-25.
30. Śliwka M., Baran A., Wieczorek J. 2013. Evaluation of toxic metal bioaccumulation in a reservoir of flotation tailings. Polish Journal of Environmental Studies, 22 (3), 909-914.

31. Śliwka M., Uliasz-Bocheńczyk A., Pawul. 2017. An appraisal of the properties of bottom waste obtained from bio-mass congestion to estimate the ways of its environmental use. Polish Journal of Chemical Technology, 19 (2), 33-37.

32. Traczewska T.M. 2011. Biologiczne metody oceny skażenia środowiska. Oficyna Wydawnicza Politechniki Wrocławskiej, Wrocław.

33. Uliasz-Bocheńczyk A., Mazurkiewicz M., Mokrzycki E. 2015. Fly ash from energy production - a waste, by product and raw material. Mineral Resources Management, 31, 139-150.

34. Yao Z.T., Ji X.S., Sarker P.K., Tang J.H., Ge L.Q., Xia M.S., Xi Y.Q. 2015. A comprehensive review on the applications of coal fly ash. Earth-Science Reviews, 141, 105-121. 